\title{
research
}

\section{Outcome of severe infections in afebrile neutropenic cancer patients}

\author{
Ksenija Strojnik¹, Ksenija Mahkovic-Hergouth², Barbara Jezersek Novakovic ${ }^{1}$, \\ Bostjan Seruga ${ }^{1,3}$
}

\author{
${ }^{1}$ Department of Medical Oncology, Institute of Oncology Ljubljana, Ljubljana, Slovenia \\ ${ }^{2}$ Department of Anesthesiology and Intensive Care, Institute of Oncology, Ljubljana, Slovenia \\ 3 University of Ljubljana, Medical Faculty, Ljubljana, Slovenia
}

Radiol Oncol 2016; 50(4): 442-448.

Received: 28 October 2015

Accepted: 5 November 2015

Correspondence to: Ksenija Strojnik, M.D., Department of Medical Oncology, Institute of Oncology Ljubljana, Zaloška 2, 1000 Ljubljana, Slovenia. Phone: +386 15879 282; Fax: +386 15879 303; E-mail: kstrojnik@onko-i.si

Disclosure: The authors declare no conflict of interest.

Results of this analysis were in part presented at the MASCC/ISOO International Symposium on Supportive Care in Cancer in New York City in 2012 (oral presentation of the abstract \#734).

Background. In some neutropenic cancer patients fever may be absent despite microbiologically and/or clinically confirmed infection. We hypothesized that afebrile neutropenic cancer patients with severe infections have worse outcome as compared to cancer patients with febrile neutropenia.

Patients and methods. We retrospectively analyzed all adult cancer patients with chemotherapy-induced neutropenia and severe infection, who were admitted to the Intensive Care Unit at our cancer center between 2000 and 2011. The outcome of interest was 30-day in-hospital mortality rate. Association between the febrile status and in-hospital mortality rate was evaluated by the Fisher's exact test.

Results. We identified 69 episodes of severe neutropenic infections in 65 cancer patients. Among these, 9 (13\%) episodes were afebrile. Patients with afebrile neutropenic infection presented with hypotension, severe fatigue with inappetence, shaking chills, altered mental state or cough and all of them eventually deteriorated to severe sepsis or septic shock. Overall 30-day in-hospital mortality rate was 55.1\%. Patients with afebrile neutropenic infection had a trend for a higher 30-day in-hospital mortality rate as compared to patients with febrile neutropenic infection (78\% vs. $52 \%, p=0.17)$.

Conclusions. Afebrile cancer patients with chemotherapy-induced neutropenia and severe infections might have worse outcome as compared to cancer patients with febrile neutropenia. Patients should be informed that severe neutropenic infection without fever can occasionally occur during cancer treatment with chemotherapy.

Key words: afebrile infection; fever; neutropenia; hypothermia; cancer

\section{Introduction}

Infections are important cause of morbidity and mortality in cancer patients. ${ }^{1}$ Neutropenia is a major risk factor for the development of infection in cancer patients undergoing treatment with chemotherapy. ${ }^{2,3}$ Fever remains the most prevalent and evident sign of infection in neutropenic cancer patients and early initiation of broad-spectrum antibiotic therapy significantly reduces mortality in these patients. ${ }^{4-7}$
Fever is a phylogenetically ancient host defense response to variety of infectious and non-infectious triggers. It is a result of upregulation of the hypothalamic thermostatic set point due to the complex interplay between endogenous and exogenous pyrogens, enzymatic and neuronal pathways and endogenous antipyretic neuropeptides and hormones. ${ }^{8-11}$ Pyrogenic cytokines concurrently trigger production of acute phase reactants and stimulate activation of various metabolic, endocrinologic and immunologic systems. ${ }^{12}$ Data from clinical 
observations and observational studies show that fever may have a beneficial effect on morbidity and mortality caused by the non-life-threatening infections. ${ }^{8,11,12}$ However, in some neutropenic cancer patients fever may be absent despite microbiologically and/or clinically confirmed infection. ${ }^{5}$ According to the Infectious Disease Society of America (IDSA) and some other guidelines afebrile neutropenic patients with new signs or symptoms of infection are considered to be at high-risk for complications and therefore prompt use of empirical antimicrobial agents is recommended. ${ }^{13-15}$ Nevertheless, the level of evidence for this recommendation is weak (B-III) and is based on the extensive clinical experience of the Panel members. ${ }^{13}$

Afebrile infections are not unique to neutropenic cancer patients. Even more, published data shows that non-neutropenic patients with afebrile severe infections, especially those with hypothermia, have higher mortality rates compared to febrile non-neutropenic patients. ${ }^{8,16,17}$

We conducted a retrospective study to evaluate the incidence and characteristics of severe infections in afebrile neutropenic cancer patients undergoing treatment with chemotherapy at our cancer center. Furthermore, we hypothesized that afebrile neutropenic cancer patients with severe infections have worse outcome as compared to cancer patients with febrile neutropenia.

\section{Patients and methods}

\section{Study population and data collection}

We performed an electronic database search to identify all adult cancer patients, who were transferred from the Department of Medical Oncology to the Intensive Care Unit (ICU) at the Institute of Oncology Ljubljana due to the severe neutropenic infection between January 2000 and December 2011. All eligible patients for this study were required to have a severe infection due to a chemotherapy-induced neutropenia. Multiple episodes of neutropenic infections in one patient were considered as separate events. All information on relevant patients' characteristics, cancer treatment and episodes of infections were retrieved retrospectively from patients' charts. All data were extracted by a single author.

Febrile neutropenic infections were defined as at least one axillary body temperature measurement of $\geq 38^{\circ} \mathrm{C}$ in the presence of neutropenia (absolute neutrophil count $<1 \times 10^{9} / 1$ at the time of diagnosis of infection with further decline to $<0.5 \times 10^{9} / 1$ during the following days). Afebrile neutropenic infections were defined as a maximum axillary body temperature $<38^{\circ} \mathrm{C}$ within 72 hours of diagnosis of neutropenic infection, which had to be microbiologically and/or clinically documented. Severe neutropenia was defined as an absolute neutrophil count $\leq 0.1 \times 10^{9} / 1$.

Infection was considered microbiologically documented when a positive culture was yielded from the site of infection, and clinically documented when there were clinical and/or radiological signs of infection without microbiological confirmation. Characteristics of organisms isolated from blood cultures were recorded. At least two positive blood culture sets were required when coagulase-negative staphylococci or other potential skin contaminants (e.g. Corynebacterium spp., Propionibacterium spp., Bacillus spp.) were isolated. Polymicrobial bacteremia was defined as more than one organism isolated from blood culture specimens obtained within 24 hours of the first positive blood culture specimen in a single patient. ${ }^{18}$

We calculated the Multinational Association for Supportive Care in Cancer (MASCC) Risk Index score for each patient as described by Klastersky et al. ${ }^{19}$ Comorbidities were evaluated using the adult comorbidity evaluation-27 index (ACE-27) and Charlson comorbidity index (CCI). ${ }^{20,21}$ Severe sepsis and septic shock were defined according to the established 2001 International Sepsis Definitions Conference criteria. ${ }^{22}$

Our retrospective study was approved by the Institutional Review Board and Ethics Committee (\#ERID-KESOPKR/74).

\section{Statistical analysis}

We used descriptive statistics to describe relevant patients' characteristics. The outcome of interest was 30-day in-hospital mortality rate, as proposed by Feld et al. ${ }^{23}$ Association between the outcome and different prognostic factors and comparison of different characteristics between febrile and afebrile patients were evaluated using Chi-square or Fisher's exact test as appropriate. To compare mean time from the diagnosis of neutropenic infection to the ICU admission between afebrile and febrile patients we used independent-samples t-test. Due to the small number of events a multivariate analysis was not feasible. All significance tests were twosided using an alpha level of 0.05 . No correction was applied for multiple statistical testing. 
TABLE 1. Baseline patients' characteristics, cancer type and treatment

\begin{tabular}{|c|c|c|}
\hline Characteristics & & $N(\%)(n=69)$ \\
\hline $\begin{array}{l}\text { Median age } \\
\text { (range) }\end{array}$ & Elderly (> 65 years) & $\begin{array}{c}58 \text { years }(31-86) \\
28(40.6 \%)\end{array}$ \\
\hline Sex & $\begin{array}{l}\text { Male } \\
\text { Female }\end{array}$ & $\begin{array}{l}42(60.9 \%) \\
27(39.1 \%)\end{array}$ \\
\hline Cancer type & $\begin{array}{l}\text { Lymphoma } \\
\text { Solid tumors }\end{array}$ & $\begin{array}{l}52(75.4 \%) \\
17(24.6 \%)\end{array}$ \\
\hline $\begin{array}{l}\text { Chemotherapy } \\
\text { treatment intent }\end{array}$ & 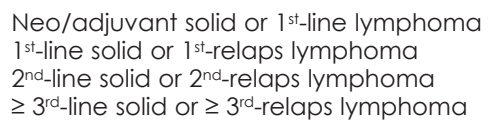 & $\begin{array}{l}35(50.7 \%) \\
13(18.8 \%) \\
12(17.4 \%) \\
9(13.1 \%)\end{array}$ \\
\hline $\mathrm{CCl}$ & $\begin{array}{l}\text { Low }(0) \\
\text { Medium }(1-2) \\
\text { High }(3-4) \\
\text { Very high }(\geq 5)\end{array}$ & $\begin{array}{l}28(40.6 \%) \\
30(43.5 \%) \\
8(11.6 \%) \\
3(4.3 \%)\end{array}$ \\
\hline ACE-27 & $\begin{array}{l}\text { None (G0) } \\
\text { Mild (G1) } \\
\text { Moderate (G2) } \\
\text { Severe (G3) }\end{array}$ & $\begin{array}{l}17(24.6 \%) \\
16(23.2 \%) \\
13(18.9 \%) \\
23(33.3 \%)\end{array}$ \\
\hline $\begin{array}{l}\text { WHO } \\
\text { performance } \\
\text { status }\end{array}$ & $\begin{array}{l}0-2 \\
3-4\end{array}$ & $\begin{array}{l}54(78.3 \%) \\
15(21.7 \%)\end{array}$ \\
\hline $\begin{array}{l}\text { Bone marrow } \\
\text { infiltration }\end{array}$ & $\begin{array}{l}\text { Yes } \\
\text { No } \\
\text { Unknown }\end{array}$ & $\begin{array}{l}22(31.9 \%) \\
29(42.0 \%) \\
18(26.1 \%)\end{array}$ \\
\hline $\begin{array}{l}\text { Previous } \\
\text { neutropenic } \\
\text { infection }\end{array}$ & $\begin{array}{l}\text { Yes } \\
\text { No }\end{array}$ & $\begin{array}{l}24(34.8 \%) \\
45(65.2 \%)\end{array}$ \\
\hline Site of infectiona & 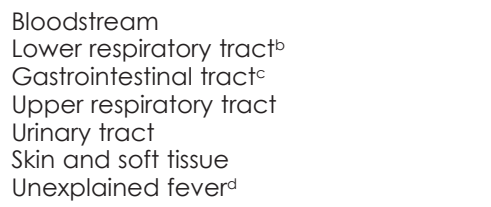 & $\begin{aligned} 25 & (36.2 \%) \\
25 & (36.2 \%) \\
13 & (18.8 \%) \\
2 & (2.9 \%) \\
1 & (1.5 \%) \\
1 & (1.5 \%) \\
2 & (2.9 \%)\end{aligned}$ \\
\hline $\begin{array}{l}\text { Time period of } \\
\text { ICU admission } \\
\text { (year) }\end{array}$ & $\begin{array}{l}2000-2003 \\
2004-2011\end{array}$ & $\begin{array}{l}8(13.6 \%) \\
51(86.4 \%)\end{array}$ \\
\hline
\end{tabular}

$\mathrm{ACE}-27$ = adult comorbidity evaluation -27 index $\mathrm{CCl}=$ Charlson comorbidity index; $\mathrm{ICU}=$ Intensive Care Unit; $\mathrm{WHO}=$ World Health Organization

a Includes 53 episodes of microbiologically documented infection (MDI) and 16 episodes of clinically documented infection (CDI)

b Pneumonias with 13 cases of MDI and 12 cases of CDI with radiological signs only

c Includes cases of cholecystitis, peritonitis, neutropenic enterocolitis

${ }^{a} \mathrm{CDI}$ with fever and signs of septic shock tion in the ICU were 14 days (range 1-52 days) and 5 days (range 1-34 days), respectively.

A median MASCC score was 14 (range 0-21). Only two episodes were considered low-risk according to the MASCC score. In the remaining 67 high-risk episodes, 35 had the MASCC score $<15$. Thirty patients $(43.5 \%)$ had severe neutropenia at the onset of neutropenic infection. In $21(30.4 \%)$ and $19(27.5 \%)$ episodes patients received either prophylactic or therapeutic granulocyte-colony stimulating factors (G-CSF), respectively.

Infections were microbiologically documented in $53(76.8 \%)$ episodes. Out of the remaining 16 clinically documented infections, 13 were confirmed radiologically or with ultrasound (12 pneumonias and one cholecystitis), two patients had fever with clinical signs of septic shock and one had cellulitis. Details about the sites of infection are listed in Table 1.

Bloodstream and lower respiratory tract were the most common sites of infection. The most common microbiological isolates from blood cultures were gram-negative bacteria in $72 \%$ (E.coli in eight, Pseudomonas aeruginosa in three, Stenotrophomonas maltophilia in three, Klebsiella pneumoniae in two, Acinetobacter baumannii in one and unidentified non-fermenting gram-negative bacteria in one episode). Gram-positive bacteria were isolated from three out of 25 positive blood cultures (Enterococcus faecalis, Streptococcus pneumoniae and methicillin-resistant Staphylococcus aureus). In one case anaerobic bacteremia was identified (Clostridium tertium). There were two cases of polymicrobial blood infection (with E.coli, Enterococcus faecalis and Candida albicans in one, and Enterobacter asburiae, Proteus mirabilis and Enterococcus faecalis in the other). Candidemia with Candida albicans was seen in one case.

Median time from the diagnosis of neutropenic infection to the ICU admission was 10 hours (range 0 hours -27 days). Reasons for ICU admission were septic shock in $39(56.5 \%)$ patients, severe sepsis in $20(29 \%)$ patients, pulmonary thromboembolism in three patients and seven patients were already in the ICU at the onset of neutropenic infection. In $61(88.4 \%), 30(43.5 \%), 6(8.7 \%)$ and $11(15.9 \%)$ episodes vasopressors and/or inotropes, mechanical ventilation, dialysis and surgery were required, respectively.

\section{Afebrile neutropenic infections}

Sixty $(87 \%)$ episodes of neutropenic infections were febrile and only 9 (13\%) episodes, which oc- 
curred in 9 patients, were afebrile. Median age of patients with afebrile infection was 56 years (range 41-82 years). All were considered high-risk with a median MASCC score of 13 (range 7-18). There were no differences between patients with afebrile and febrile neutropenic infection with regard to age, sex, comorbidities, status at the time of diagnosis of neutropenic infection, MASCC score, severity of neutropenia, type of infection, rate of Gram negative or polymicrobial bacteremias and time to the ICU admission. However, patients with afebrile neutropenic infection were more likely to have solid tumors (Table 2).

Five patients were afebrile throughout the episode of infection, in two patients there was a history of fever at home, and two patients developed fever on the 5th and 7th day of hospitalization, respectively, due to a secondary, health care-associated infection. The highest recorded temperature within 72 hours of diagnosis of neutropenic infection was $37.2^{\circ} \mathrm{C}$ or lower in five patients, and between 37.4 and $37.8^{\circ} \mathrm{C}$ in the remaining four patients.

Six patients $(66.7 \%)$ received drugs with potential antipyretic effect (non-steroidal anti-inflammatory drugs, paracetamol, corticosteroids, metamizole) at least once within 48 hours prior and 72 hours after the diagnosis of neutropenic infection, five intermittently and only one continuously. Similarly, $56.7 \%$ of patients with febrile neutropenic infection received drugs with potential antipyretic effect $(p=0.73)$. There was no difference in the rate of afebrile neutropenic infections in patients who received drugs with antipyretic effect compared to patients who did not (15\% vs. $10.3 \%$, respectively, $\mathrm{p}=0.72$ ).

Presenting clinical signs and symptoms of infection in afebrile neutropenic patients were hypotension, severe fatigue with inappetence, shaking chills, altered mental state and cough, in descending order of frequency. All of them eventually deteriorated to severe sepsis or septic shock.

Eight patients $(89 \%)$ had microbiologically documented infections: four had gram-negative bacteremias (two E.coli, one Klebsiella pneumoniae, one Pseudomonas aeruginosa), two had polymicrobial peritonitis, one had a gram-positive pneumonia and one had a gram-negative urinary tract infection but without blood culture drawn. One patient had a radiologically documented pneumonia.

\section{Outcome}

In all patients with severe neutropenic infection 30day in-hospital mortality rate was $55.1 \%$. In four
TABLE 2. Comparison between patients with afebrile and febrile neutropenic infection

\begin{tabular}{|c|c|c|c|c|}
\hline Characteristics & & $\begin{array}{c}\text { Afebrile } \\
(n=9)\end{array}$ & $\begin{array}{l}\text { Febrile } \\
(n=60)\end{array}$ & $p$-value \\
\hline Age (years) & $\begin{array}{l}>65 \\
\leq 65\end{array}$ & $\begin{array}{l}4 \\
5\end{array}$ & $\begin{array}{l}24 \\
36\end{array}$ & 1.0 \\
\hline Sex & $\begin{array}{l}\text { Male } \\
\text { Female }\end{array}$ & $\begin{array}{l}4 \\
5\end{array}$ & $\begin{array}{l}38 \\
22\end{array}$ & 0.28 \\
\hline Cancer type & $\begin{array}{l}\text { Lymphoma } \\
\text { Solid tumors }\end{array}$ & $\begin{array}{l}3 \\
6\end{array}$ & $\begin{array}{l}49 \\
11\end{array}$ & 0.005 \\
\hline $\mathrm{CCl}$ & $\begin{array}{l}\text { Low }(0) \\
\text { Medium - very high }(\geq 1)\end{array}$ & $\begin{array}{l}5 \\
4\end{array}$ & $\begin{array}{l}23 \\
37\end{array}$ & 0.47 \\
\hline ACE-27 & $\begin{array}{l}\text { None - mild (G0-1) } \\
\text { Moderate - severe (G2-3) }\end{array}$ & $\begin{array}{l}5 \\
4\end{array}$ & $\begin{array}{l}28 \\
32\end{array}$ & 0.73 \\
\hline $\begin{array}{l}\text { Status at } \\
\text { diagnosis }\end{array}$ & $\begin{array}{l}\text { Inpatient } \\
\text { Outpatient }\end{array}$ & $\begin{array}{l}3 \\
6\end{array}$ & $\begin{array}{l}34 \\
26\end{array}$ & 0.29 \\
\hline MASCC score & $\begin{array}{l}<15 \\
\geq 15\end{array}$ & $\begin{array}{l}5 \\
4\end{array}$ & $\begin{array}{l}30 \\
30\end{array}$ & 1.0 \\
\hline $\begin{array}{l}\text { Severe } \\
\text { neutropenia }\end{array}$ & $\begin{array}{l}\text { Yes } \\
\text { No }\end{array}$ & $\begin{array}{l}3 \\
6\end{array}$ & $\begin{array}{l}27 \\
33\end{array}$ & 0.72 \\
\hline Type of infection & $\begin{array}{l}\text { MDI } \\
\text { CDI }\end{array}$ & $\begin{array}{l}8 \\
1\end{array}$ & $\begin{array}{l}45 \\
15\end{array}$ & 0.33 \\
\hline $\begin{array}{l}\text { Bloodstream } \\
\text { infection }\end{array}$ & $\begin{array}{l}\text { Gram negative }{ }^{b} \\
\text { non-Gram negative }\end{array}$ & $\begin{array}{l}4 \\
0\end{array}$ & $\begin{array}{c}16 \\
5\end{array}$ & 0.55 \\
\hline $\begin{array}{l}\text { Mean time to } \\
\text { the ICU (hours) }\end{array}$ & & 41 & 54 & 0.73 \\
\hline
\end{tabular}

ACE-27 = adult comorbidity evaluation-27 index; $\mathrm{CCI}=$ Charlson comorbidity index; $\mathrm{CDI}=$ clinically documented infection; ICU = Intensive Care Unit; MASCC = Multinational Association for Supportive Care in Cancer; $\mathrm{MDI}=$ microbiologically documented infection

${ }^{a} n=25$

b also includes polymicrobial bacteremias with at least one Gram negative bacteria

patients, who experienced two separate episodes of severe neutropenic infection, two survived both episodes and two had fatal outcome during the second episode. Thirty (79\%) deaths occurred in the ICU and the remaining deaths occurred after the ICU discharge. Cause of death was attributed to the uncontrolled infection in 31 patients, pulmonary thromboembolism in three, comorbidities in two, and cancer progression in two patients. In patients with afebrile neutropenic infection episode 30 -day in-hospital mortality rate was $78 \%$. While in six patients death occurred due to the uncontrolled infection, one patient died due to the cancer progression. The remaining two patients who survived had radiologically documented pneumonia and Pseudomonas aeruginosa bacteremia.

Prognostic factors associated with 30-day inhospital mortality are listed in Table 3. Patients with afebrile neutropenic infection had a trend for a higher 30-day in-hospital mortality rate as compared to patients with febrile neutropenic infection $(78 \%$ vs. 52\%, p = 0.17). MASCC score < $15(71 \%$ vs. $38 \%, \mathrm{p}=0.006)$, lactic acidosis $(100 \%$ vs. $53 \%$, p $=0.04)$ and use of mechanical ventilation $(87 \%$ vs. $31 \%, \mathrm{p}<0.001$ ) were all associated with significantly higher 30-day in-hospital mortality rates. We did 
TABLE 3. Prognostic factors associated with 30-day in-hospital mortality

\begin{tabular}{|c|c|c|c|c|}
\hline Prognostic factor & & $\begin{array}{c}\text { Died } \\
(n=38)\end{array}$ & $\begin{array}{l}\text { Survived } \\
(n=31)\end{array}$ & $p$-value \\
\hline Age (years) & $\begin{array}{l}>65 \\
\leq 65\end{array}$ & $\begin{array}{l}17 \\
21\end{array}$ & $\begin{array}{l}11 \\
20\end{array}$ & 0.44 \\
\hline Cancer type & $\begin{array}{l}\text { Lymphoma } \\
\text { Solid tumors }\end{array}$ & $\begin{array}{c}29 \\
9\end{array}$ & $\begin{array}{c}23 \\
8\end{array}$ & 0.84 \\
\hline $\mathrm{CCl}$ & $\begin{array}{l}\text { Low }(0) \\
\text { Medium - very high } \\
(\geq 1)\end{array}$ & $\begin{array}{l}17 \\
21\end{array}$ & $\begin{array}{l}11 \\
20\end{array}$ & 0.44 \\
\hline ACE-27 & $\begin{array}{l}\text { None - mild (G0-1) } \\
\text { Moderate - severe } \\
\text { (G2-3) }\end{array}$ & $\begin{array}{l}20 \\
18\end{array}$ & $\begin{array}{l}13 \\
18\end{array}$ & 0.38 \\
\hline $\begin{array}{l}\text { G-CSF } \\
\text { prophylactic }\end{array}$ & $\begin{array}{l}\text { Yes } \\
\text { No }\end{array}$ & $\begin{array}{l}14 \\
24\end{array}$ & $\begin{array}{c}7 \\
24\end{array}$ & 0.2 \\
\hline $\begin{array}{l}\text { G-CSF } \\
\text { therapeutic }\end{array}$ & $\begin{array}{l}\text { Yes } \\
\text { No }\end{array}$ & $\begin{array}{l}12 \\
26\end{array}$ & $\begin{array}{c}7 \\
24\end{array}$ & 0.41 \\
\hline Fever status & $\begin{array}{l}\text { Febrile } \\
\text { Afebrile }\end{array}$ & $\begin{array}{l}31 \\
7\end{array}$ & $\begin{array}{c}29 \\
2\end{array}$ & 0.17 \\
\hline MASCC score & $\begin{array}{l}<15 \\
\geq 15\end{array}$ & $\begin{array}{l}25 \\
13\end{array}$ & $\begin{array}{l}10 \\
21\end{array}$ & 0.006 \\
\hline $\begin{array}{l}\text { Bloodstream } \\
\text { infection }\end{array}$ & $\begin{array}{l}\text { Yes } \\
\text { No }\end{array}$ & $\begin{array}{l}15 \\
23\end{array}$ & $\begin{array}{l}10 \\
21\end{array}$ & 0.54 \\
\hline $\begin{array}{l}\text { Mechanical } \\
\text { ventilation }\end{array}$ & $\begin{array}{l}\text { Yes } \\
\text { No }\end{array}$ & $\begin{array}{l}26 \\
12\end{array}$ & $\begin{array}{c}4 \\
27\end{array}$ & $P<0.001$ \\
\hline Lactic acidosisa & $\begin{array}{l}\text { Yes } \\
\text { No }\end{array}$ & $\begin{array}{c}7 \\
31\end{array}$ & $\begin{array}{c}0 \\
27\end{array}$ & 0.04 \\
\hline $\begin{array}{l}\text { Time period of } \\
\text { ICU admission } \\
\text { (year) }\end{array}$ & $\begin{array}{l}2000-2003 \\
2004-2011\end{array}$ & $\begin{array}{c}4 \\
34\end{array}$ & $\begin{array}{c}4 \\
27\end{array}$ & 1.0 \\
\hline
\end{tabular}

ACE-27 = adult comorbidity evaluation-27 index; $\mathrm{CCl}=$ Charlson comorbidity index; G-CSF = granulocyte-colony stimulating factors; $\mathrm{ICU}=$ Intensive Care Unit; MASCC = Multinational Association for Supportive Care in Cancer;

$a_{n}=65$ nia. Sickles et al. studied clinical signs of the five most common localized infections (pharyngitis, skin infection, pneumonia, anorectal infection and urinary tract infection) in neutropenic and nonneutropenic cancer patients. They reported that fever was much more common in neutropenic patients than in non-neutropenic ones. When analyzing all infection sites together, fever (defined as > $38^{\circ} \mathrm{C}$ ) was absent in $2-10 \%$ of all patients, depending on severity of neutropenia (in those with absolute neutrophil count $\leq 0.1 \times 10^{9} / 1$ fever was absent in only $2 \%) .^{5}$

Published data show that $18-40 \%$ and $10-20 \%$ of non-neutropenic patients develop normothermia or hypothermia, respectively, despite infection with severe sepsis or septic shock. ${ }^{916,24-29}$ However, definitions of fever, normothermia and hypothermia differed in published studies. Recently published study by Weinkove et al. reported $23 \%$ incidence of afebrile neutropenic sepsis in subgroup of patients with hematological malignancies $(20 \%$ of these had a peak body temperature below $36.5^{\circ} \mathrm{C}$ and the remaining between 36.5 and $37.4^{\circ} \mathrm{C}$ during first 24 hours in the ICU). ${ }^{30}$

According to our results, overall mortality rate in the ICU was $55.1 \%$ and was in line with published results of other studies. ${ }^{31-35}$ Lower MASCC score (MASCC score $<15$ ), need for mechanical ventilation and lactic acidosis at the time of the ICU admission were associated with significantly higher 30-day in-hospital mortality (Table 3). These observations are in line with previously reported studies in patients with severe infections. $32,34,36-39$ Although studies have reported improved survival rates of critically ill cancer patients during the past decade as compared to later time periods, in part due to implementation of the Surviving Sepsis Campaign guidelines, we did not find any significant difference in mortality rates between patients treated in the ICU before and after 2004 (50 vs. 55\%, respectively, $\mathrm{p}=1.0$ ) (Table 3). ${ }^{40,41}$ Furthermore, we observed a trend for a higher mortality rate in patients with afebrile neutropenic infections as compared to patients with febrile neutropenic infections (78 vs. 52\%, p = 0.17) (Table 3). Published data show that patients with severe infections and hypothermia more likely develop septic shock as compared to those who are not hypothermic. ${ }^{25,27,29}$ Furthermore, reported mortality rates in this subpopulation are consistently higher compared to normothermic or febrile patients, and are in range between $50-80 \% .{ }^{24-29,42}$ In contrast, data on patients with normothermic response to severe infection are inconsistent. ${ }^{24-28}$ Results of recently published large 
multicentric retrospective registry study, which included 4027 patients with neutropenic sepsis, showed that patients with neutropenic sepsis and peak temperature below $36.5^{\circ} \mathrm{C}$ (hypothermia) within the first 24 hours of admission to the ICU had approximately two-fold higher risk for in-hospital death as compared to normothermic (defined as temperatures between 36.5 and $37.4^{\circ} \mathrm{C}$ ) patients. They did not observe any significant difference in mortality between normothermic and febrile (peak temperature of $\geq 37.5^{\circ} \mathrm{C}$ ) patients. Similar was observed in a subgroup of patients with neutropenic sepsis and hematological malignancy. ${ }^{30}$ Due to the retrospective nature of our study and due to the small number of patients with afebrile infections further subset-analyses (hypothermic vs. normothermic $v$ s. febrile) were not feasible.

Use of drugs with antipyretic effect (e.g. some drugs used for the management of pain, corticosteroids) could potentially block the development of fever, which may delay presentation of these patients with serious infections to medical services. However, in our study there were no differences in the use of drugs with antipyretic effect in the febrile and afebrile subgroups of patients. Also, we did not find any differences in the rate of afebrile neutropenic infections in patients who received drugs with antipyretic effect and those who did not. Results of recently published study showed that feeling unwell in the absence of fever, which is a key marker of neutropenic sepsis, might discourage patients from contacting a doctor. ${ }^{43}$ Delay of treatment with effective antimicrobial therapy in patients with severe neutropenia and bacteremia or septic shock is associated with increased mortality rates. ${ }^{44,45}$ Patients on chemotherapy treatment should be informed that, although rarely, fever may be absent even in severe neutropenic infections and warned of possible other signs and symptoms of infection. In our study we observed that patients with afebrile neutropenic infection can present with hypotension, severe fatigue with inappetence, shaking chills, altered mental state or cough.

Our study has several limitations. First, this was a retrospective, single center study with a small sample size of heterogeneous patient population and therefore our findings are only hypothesisgenerating. Only patients with solid tumors and lymphomas are treated at our center; patients with acute leukemias who frequently experience neutropenic infections were thus excluded from our analysis. Second, due to the small number of patients with afebrile infection a multivariate analysis as well as further subset comparisons (e.g. hypothermic $v s$. normothermic $v s$. febrile patients) were not feasible. Third, due to retrospective nature of our study we were not able to assess the potential impact of delayed effective antimicrobial therapy on the outcome of febrile and afebrile patients. Fourth, definition of febrile and afebrile episodes in our study may be flawed as axillary body measurement, used in our study, correlates least accurately with core body temperature with as much as $0.9^{\circ} \mathrm{C}$ variation. ${ }^{46}$ According to the international guidelines for the management of infections in neutropenic cancer patients body temperature should be measured orally, while axillary measurements are discouraged. ${ }^{13,15}$ Finally, we evaluated all episodes of severe neutropenic infections (with four patients having two separate episodes of febrile neutropenic infections), as occurring in real life practice, and thus risked potential statistical bias. ${ }^{23}$

In conclusion, afebrile infections in neutropenic cancer patients are rare. However, in cancer patients with chemotherapy-induced neutropenia and severe infections, afebrile patients might be at higher risk of death due to the complications of infection as compared to patients with febrile neutropenia. In addition, we identified lower MASCC score (MASCC score $<15$ ), need for mechanical ventilation and lactic acidosis at the time of the ICU admission as negative prognostic factors for outcome. Patients on potentially myelosuppressive systemic cancer treatment should be informed that occasionally fever may be absent during the episode of neutropenic infection, and that they should immediately seek medical attention if signs or symptoms suggestive of infection occur, even in the absence of fever.

\section{References}

1. Viscoli C. The evolution of the empirical management of fever and neutropenia in cancer patients. J Antimicrob Chemother 1998; 41(Suppl D): 65-80.

2. Bodey GP, Buckley M, Sathe YS, Freireich EJ. Quantitative relationships between circulating leukocytes and infection in patients with acute leukemia. Ann Intern Med 1966; 64: 328-40.

3. Zwitter M, Stanic K, Rajer M, Kern I, Vrankar M, Edelbaher N, et al. Intercalated chemotherapy and erlotinib for advanced NSCLC: high proportion of complete remissions and prolonged progression-free survival among patients with EGFR activating mutations. Radiol Oncol 2014; 48: 361-8.

4. Klastersky J, Awada A, Paesmans M, Aoun M. Febrile neutropenia: a critical review of the initial management. Crit Rev Oncol Hematol 2011; 78: 185-94.

5. Sickles EA, Greene WH, Wiernik PH. Clinical presentation of infection in granulocytopenic patients. Arch Intern Med 1975; 135: 715-9.

6. Rolston KI. Neutropenic fever and sepsis: evaluation and management. Cancer Treat Res 2014; 161: 181-202.

7. Kukec RR, Grabnar I, Vovk T, Mrhar A, Kovac V, Cufer T. Febrile neutropenia in chemotherapy treated small-cell lung cancer patients. Radiol Oncol 2015; 49: $173-80$. 
8. Launey $Y$, Nesseler $N$, Mallédant $Y$, Seguin P. Clinical review: fever in septic ICU patients-friend or foe? Crit Care 2011; 15: 222.

9. Schortgen F. Fever in sepsis. Minerva Anestesiol 2012; 78: 1254-64.

10. Kluger MJ, Kozak W, Conn CA, Leon LR, Soszynski D. Role of fever in disease. Ann N Y Acad Sci 1998; 856: 224-33.

11. Hasday JD, Fairchild KD, Shanholtz C. The role of fever in the infected host. Microbes Infect 2000; 2: 1891-904.

12. Mackowiak PA. Concepts of fever. Arch Intern Med 1998; 158: 1870-81.

13. Freifeld AG, Bow EJ, Sepkowitz KA, Boeckh MJ, Ito Jl, Mullen CA, et al. Clinical practice guideline for the use of antimicrobial agents in neutropenic patients with cancer: 2010 update by the Infectious Diseases Society of America. Clin Infect Dis 2011; 52: 56-93.

14. De Naurois J, Novitzky-Basso I, Gill MJ, Marti FM, Cullen MH, Roila F. Management of febrile neutropenia: ESMO clinical practice guidelines. Ann Oncol 2010; 21(Suppl 5): 252-6.

15. National Comprehensive Cancer Network. NCCN Clinical practice guidelines in oncology: Prevention and treatment of cancer-related infections. Version 2. [Cited 11 Jun 2015]. Available at http://www.ncen.org/professionals/ physician_gls/pdf/infections.pdf.

16. Kushimoto S, Yamanouchi S, Endo T, Sato S, Nomura R, Fujita M, et al. Body temperature abnormalities in non-neurological critically ill patients: a review of the literature. J Intensive Care 2014; 2: 14

17. Hasday JD, Garrison A. Antipyretic therapy in patients with sepsis. Clin Infect Dis 2000; 31(Suppl 5): 234-41.

18. Rolston KVI, Bodey GP, Safdar A. polymicrobial infection in patients with cancer: an underappreciated and underreported entity. Clin Infect Dis 2007; 45: 228-33.

19. Klastersky J, Paesmans M, Rubenstein EB, Boyer M, Elting L, Feld R, et al. The multinational association for supportive care in cancer risk index: multinational scoring system for identifying low-risk febrile neutropenic cancer patients. J Clin Oncol 2000; 18: 3038-51.

20. Piccirillo JF, Tierney RM, Costas I, Grove L, Spitznagel EL. Prognostic importance of comorbidity in a hospital-based cancer registry. JAMA 2004; 291 2441-7.

21. Charlson ME, Pompei P, Ales KL, MacKenzie CR. A new method of classifying prognostic comorbidity in longitudinal studies: development and validation. J Chronic Dis 1987; 40: 373-83.

22. Levy MM, Fink MP, Marshall JC, Abraham E, Angus D, Cook D, et al. 2001 SCCM/ESICM/ACCP/ATS/SIS International Sepsis Definitions Conference. Crit Care Med 2003; 31: 1250-6.

23. Feld R, Paesmans M, Freifeld AG, Klastersky J, Pizzo PA, Rolston KVI, et al. Methodology for clinical trials involving patients with cancer who have febrile neutropenia: updated guidelines of the Immunocompromised Host Society/Multinational Association for Supportive Care in Cancer, with emphasis on outpatient studies. Clin Infect Dis 2002; 35:1463-8.

24. Peres Bota D, Lopes Ferreira F, Mélot C, Vincent JL. Body temperature alterations in the critically ill. Intensive Care Med 2004; 30: 811-6.

25. Kushimoto S, Gando S, Saitoh D, Mayumi T, Ogura H, Fujishima S, et al. The impact of body temperature abnormalities on the disease severity and outcome in patients with severe sepsis: an analysis from a multicenter, prospective survey of severe sepsis. Crit Care 2013; 17: R271.

26. Young PJ, Saxena M, Beasley R, Bellomo R, Bailey M, Pilcher D, et al. Early peak temperature and mortality in critically ill patients with or without infection. Intensive Care Med 2012; 38: 437-44.

27. Drewry AM, Fuller BM, Skrupky LP, Hotchkiss RS. The presence of hypothermia within 24 hours of sepsis diagnosis predicts persistent lymphopenia. Crit Care Med 2015; 43: 1165-9.

28. Sprung CL, Peduzzi PN, Shatney CH, Schein RM, Wilson MF, Sheagren JN, et al. Impact of encephalopathy on mortality in the sepsis syndrome. Crit Care Med 1990; 18: 801-6.

29. Clemmer TP, Fisher CJJ, Bone RC, Slotman GJ, Metz CA, Thomas FO. Hypothermia in the sepsis syndrome and clinical outcome. Crit Care Med 1992; 20: 1395-401.

30. Weinkove R, Bailey M, Bellomo R, Saxena MK, Tam CS, Pilcher DV, et al. Association between early peak temperature and mortality in neutropenic sepsis. Ann Hematol 2015; 94: 857-64.
31. Legrand M, Max A, Peigne V, Mariotte E, Canet E, Debrumetz A, et al. Survival in neutropenic patients with severe sepsis or septic shock. Crit Care Med 2012; 40: 43-9.

32. Mokart D, Darmon M, Resche-Rigon M, Lemiale V, Pene F, Mayaux J, et al. Prognosis of neutropenic patients admitted to the intensive care unit. Intensive Care Med 2015; 41: 296-303.

33. Groeger JS, Glassman J, Nierman DM, Wallace SK, Price K, Horak D, et al. Probability of mortality of critically ill cancer patients at $72 \mathrm{~h}$ of intensive care unit (ICU) management. Support Care Cancer 2003; 11: 686-95.

34. Regazzoni CJ, Irrazabal C, Luna CM, Poderoso JJ. Cancer patients with septic shock: mortality predictors and neutropenia. Support Care Cancer 2004; 12: 833-9.

35. Souza-Dantas VC, Salluh JIF, Soares M. Impact of neutropenia on the outcomes of critically ill patients with cancer: a matched case-control study. Ann Oncol 2011; 22: 2094-100.

36. Paesmans M, Klastersky J, Maertens J, Georgala A, Muanza F, Aoun M, et al. Predicting febrile neutropenic patients at low risk using the MASCC score: does bacteremia matter? Support Care Cancer 2011: 19: 1001-8.

37. Klastersky J, Ameye L, Maertens J, Georgala A, Muanza F, Aoun M, et al. Bacteraemia in febrile neutropenic cancer patients. Int J Antimicrob Agents 2007; 30(Suppl 1): 51-9.

38. Gunnerson KJ, Saul M, He S, Kellum JA. Lactate versus non-lactate metabolic acidosis: a retrospective outcome evaluation of critically ill patients. Crit Care 2006; 10: R22.

39. Mato AR, Luger SM, Heitjan DF, Mikkelsen ME, Olson E, Ujiani $C$, et al. Elevation in serum lactate at the time of febrile neutropenia (FN) in hemodynamically-stable patients with hematologic malignancies (HM) is associated with the development of septic shock within 48 hours. Cancer Biol Ther 2010; 9: 585-9.

40. Azoulay E, Soares M, Darmon M, Benoit D, Pastores S, Afessa B. Intensive care of the cancer patient: recent achievements and remaining challenges. Ann Intensive Care 2011; 1: 5.

41. Dellinger RP, Levy MM, Carlet JM, Bion J, Parker MM, Jaeschke R, et al. Surviving Sepsis Campaign: international guidelines for management of severe sepsis and septic shock: 2008. Crit Care Med 2008; 36: 296-327.

42. Tiruvoipati R, Ong K, Gangopadhyay H, Arora S, Carney I, Botha J. Hypothermia predicts mortality in critically ill elderly patients with sepsis. BMC Geriatr 2010; 10: 70.

43. Clarke RT, Bird S, Kakuchi I, Littlewood TJ, van Hamel Parsons V. The signs, symptoms and help-seeking experiences of neutropenic sepsis patients before they reach hospital: a qualitative study. Support Care Cancer 2015 23: 2687-94.

44. Kumar A, Roberts D, Wood KE, Light B, Parrillo JE, Sharma S, et al. Duration of hypotension before initiation of effective antimicrobial therapy is the critical determinant of survival in human septic shock. Crit Care Med 2006; 34: 1589-96.

45. Lin MY, Weinstein RA, Hota B. Delay of active antimicrobial therapy and mortality among patients with bacteremia: impact of severe neutropenia. Antimicrob Agents Chemother 2008; 52: 3188-94.

46. Bow EJ. Infection in neutropenic patients with cancer. Crit Care Clin 2013; 29: 411-41. 